\title{
The Origins of Chemical Warfare in the French Army
}

\section{Jonathan Krause}

\author{
$\underline{\text { Abstract }}$ \\ Following the Germans' first use of chlorine gas during the second battle of Ypres, the \\ Entente had to develop means of protection from future poison gas attacks as well as \\ systems for retaliation. This article, through the analysis of heretofore unexamined \\ archival sources, considers early French attempts at engaging in chemical warfare. \\ Contrary to the existing historiography, the French army aggressively adapted to, and \\ engaged in, chemical warfare. Indeed, the French army would be the first to fire \\ asphyxiating gas shells from field guns and, by June 1915, would pioneer the use of gas \\ as a neutralization weapon to be used in counter-battery fire, as opposed to unleashing \\ gas via canisters to engage enemy infantry. Such innovation invites a rethinking not only \\ of French gas efforts but also of the role and evolution of the French army as a whole on \\ the Western Front, a topic which the Anglophone world is in great need of examining \\ further.
}

\section{Keywords}

French, gas, chemical warfare, First World War, army

While existing historiography concerning the development of poison gases, as well as counter-measures to lethal gas after Second Ypres, is mostly very sound, the discussion of the French gas programme remains a serious weakness. The work of William Moore and Ludwig F. Haber (grandson of Fritz Haber, the Nobel Prize-winning chemist 
responsible for fixing nitrogen to make fertilizer and developing chlorine gas, among other things) remain the best overall sources for information about the use of gas on the Western Front. Both spend significant amounts of time discussing the French development of lachrymatory gas (including their Bessozi gas grenades) before and during the First World War in their respective monographs. ${ }^{1}$ These developments, especially the rifle-grenade delivery system, are well known, and are also covered in Tim Cook's work, among others. ${ }^{2}$ When it comes to discussing the development of deadly, asphyxiating gas in the French army, however, no currently published work gives a precise picture of what happened. To an extent this is due to the lack of freely available sources in the 1970s and 1980s (Trumpener laments in his 1975 article that the documentary sources on French gas were yet available), although a lack of further scholarly research has permitted many of these gaps to persist in the historiography. ${ }^{3}$ This situation has led to the existence of a range of assertions which are, at best, only partially true.

One of the most common misconceptions is that the French army stuck doggedly to the use of lachrymatory gases to the exclusion of lethal, asphyxiating variants. Haber puts forward this claim succinctly: 'In the latter part of 1915, Allied retaliation was entirely uncoordinated. The British were about to launch their first gas attack [during the battle of Loos on 25 September 1915], the French were intending to organize themselves, and the Russians talked grandly of creating clouds with chlorine, phosgene, and even less credibly, with chloropicrin.' 4 French gas efforts, according to Haber, were restricted to tear gas grenades and, from August 1915, the use of $75 \mathrm{~mm}$ shells filled with the lachrymator perchloromethyl mercaptan, which Haber condemned as being 'of no military value.' 5 While the sources in question do, correctly, give the French credit for 
being the first belligerent to use shells as a means of launching asphyxiating gas, they are unanimous in claiming that gas shells were not used until 1916, during the battle of Verdun.

Likewise in the realm of counter-measures to gas, the current historiography is not yet fully in line with the available documentation. Haber makes the very interesting point that protection from noxious vapours was already quite old and relatively advanced by 1914. ${ }^{6}$ This was owing not to fears of poison gas being used in wartime, but the practical response to the needs of miners and fire-fighters who needed means to protect themselves from the deadly conditions in which they worked. Nevertheless, the armies that would clash on the Western Front marched to war without any sort of serious protective measures against poison gas. Even after a pair of German soldiers deserted to the French and warned them of the impending gas attack at Ypres, the French are accused of having done nothing with the information. According to Moore and Haber, the reports languished above the divisional level where they were either ignored or disbelieved. This, despite the fact that one of the deserters (who gave himself up to the $11^{\mathrm{e}}$ or 'Iron' division, part of the 'Iron' XX Corps) produced his crude gas mask to validate his story. Balfourier, general commanding XX Corps d'Armée (CA), is said to have brushed off the tale as 'billevesée' or 'nonsense'. 7 The chasseurs of $11^{\mathrm{e}}$ Division d'Infanterie (DI), who had quickly designed makeshift gas-masks in response to the story of their captive, failed to convince the Algerians who came to relieve them. These same Algerians would regret their dismissal of the chasseurs' warning come 22 April.

The only monograph to seriously address the French chemical warfare programme is Olivier Lepick's La Grande Guerre Chimique, 1914-1918, published in 1998. This work, which covers the efforts of the French, British and German armies in 
the realm of chemical warfare focuses evenly on all three armies, and gives the reader the fullest analysis of French gas efforts yet. Lepick's statement that, 'in the space of a few months, chemical weapons would pass from being a technical curiosity to an indispensable component of modern warfare' is not only precisely correct, but is a statement that does not seem to have been truly embraced by the wider field, which rarely seems to give chemical warfare the prominence it deserves in the discussion of First World War operations from 1915 to $1918 .^{8}$

While Lepick does discuss the French development of asphyxiating gases in 1915 his work misattributes the earliest uses thereof (stating that the first French use of asphyxiating gas was in September 1915, as opposed to June), and does not provide as much detail as the topic of gas warfare in the French army deserves. Covering such a long period of time, and discussing developments in three major armies, the author is forced to focus only on that which he deems most important. Lepick's work is very good on the political and institutional issues surrounding gas warfare, but he is far less good at offering detailed analysis and narratives surrounding the deployment of gas on the battlefield.

The English-language literature sees the French response to the military use of poison gas as, on the whole, slow and ineffective. The French are painted as unwilling to grasp new technology (material constraints aside) or to innovate, even in the face of convincing testimonials from German deserters. They seem perpetually behind both the Germans and the British in developing both defensive and offensive systems for chemical warfare. While the French could not claim to be world-leaders in chemistry, their response and preparation for chemical warfare during the Great War was much more robust than the current historiography implies. Exploring data found in heretofore 
unexamined archival sources relating to the development of asphyxiating gas in the French army, this article focuses on the development of both poison gas (especially gas shells) and protective counter-measures. Both areas remain poorly understood and what follows sheds new light on the evolution of chemical warfare not only within the French army, but on the whole of the Western Front more generally.

\section{Protection from the Elements}

According to existing documentation (and to be taken with a pinch of salt), French research on poison gas only began in January 1915 after Grand Quartier Général (GQG) had learned that the Germans had begun similar research the month before. ${ }^{9}$

General Chavallier, director of engineering at the war ministry, wrote to General Bertrand at GQG asking if any measures were being taken to provide protection for French infantry against German gas attacks and to develop means of launching gas attacks themselves. The answer, of course, was that there was no work being done at that time and thus gas first began to be seriously studied, albeit in a slow and unorganized fashion. Very little happened until 30 March, when GQG ordered large numbers of 'engins suffocants'(tear-gas rifle-grenades) to replace the meagre stock with which the French had marched to war. ${ }^{10}$ To this was added an order issued by the war ministry on 17 April for the creation of 90,000 protective goggles to be used primarily by infantry attacking an enemy position that had been gassed. These goggles would be ready by 15 May; not only weeks too late for the first use of gas on the western front, but also grossly insufficient for the needs of the vast French army. At least partially aware of this deficiency, Joffre issued a note informing all of his armies and their logistical components that the delivery 
of these goggles would soon begin, and that they should be looked after as well as possible by the troops to whom they were issued as they could not expect to receive a second pair should the first break. ${ }^{11}$

The Germans launched their first successful gas attack against the Ypres salient on 22 April. ${ }^{12}$ Both the French and the British scrambled to collect whatever information they could from the front and from each other while racing to develop some means of combating the new weapon. On 24 April the French war minister, Alexandre Millerand, appointed André Kling, director of the Paris municipal laboratory, to take the lead in organizing research on poison gas. Millerand encouraged Joffre to decide where Kling would be most useful (whether in Paris or nearer the front), and expected that Joffre would order that Kling be given whatever help he required. ${ }^{13}$ A monsieur Heim ${ }^{14}$ worked with Kling and led the research on protective counter-measures against any future gas attack. Together they contacted M. Weiss, director of mining with the ministry of public works, who worked on the design of gas masks based on existing mining respirators. ${ }^{15}$

On 25 April Joffre ordered 100,000 cotton masks impregnated with sodium thiosulphate $\left(\mathrm{Na}_{2} \mathrm{~S}_{2} \mathrm{O}_{3}\right)$, to be delivered as soon as possible. ${ }^{16}$ The very next day Foch was in possession of 3,200 cotton masks and $500 \mathrm{~kg}$ of sodium thiosulphate. 2,500 masks and $400 \mathrm{~kg}$ sodium thiosulphate went to the Détachement d'Armée de Belgique (the Belgian Army Detachment or DAB, formerly the French Eighth Army before having two corps taken from it to reinforce Tenth Army in Artois), which was then still engaged in the second battle of Ypres. The remaining 700 and 100kg were sent to Tenth Army, which was preparing for what would become the second battle of Artois. Needless to say, this still represented a wholly insufficient number of masks. Foch wrote to Joffre on 
27 April to suggest that the mass production of respirators such as were used by miners; at this point Tenth Army had access to only 600 such devices. ${ }^{17}$

Meanwhile, Kling and his associates were busy. Three military laboratories (at Amiens, Châlons-sur-Marne, and Nancy) were taken over and converted, to focus on toxicology and medicine in relation to poison gas. ${ }^{18}$ Within days of 22 April French scientists had proved that the Germans had used chlorine gas. Through autopsies and blood tests of gas victims they could determine the effect of chlorine gas on the body and began to develop basic counter-measures. Early reports suggested two means of protection for the infantry as they awaited delivery of specialized gas masks. The infantry might dig a large pit and fill it with water (mixed with sodium thiosulphate when possible). Chlorine being water-soluble, the men could either wet cloths and cover their mouths and noses or hope that the pool itself neutralized some of the gas. In addition to this the infantry could try to disperse the gas with petards (the hope was that the explosion would scatter the chlorine gas) or even flame-throwers and concentrated riflefire. ${ }^{19}$ Despite high hopes it quickly became apparent that these stop-gap measures were ineffective and that the only real defence against gas would be the gas mask.

By early May the French efforts began to show some results. The 90,000 goggles ordered before 22 April were ready, with another 100,000 ordered and on the way. While at the time goggles were being produced at the rate of only 3,000 per diem, the war minister was confident that operations could easily be expanded to bring this number up to 10,000 a day and he suggested that Joffre outline the future goggle needs of the French army so that production could continue steadily without interruption. ${ }^{20}$ Meanwhile, antigas balaclavas impregnated with sodium thiosulphate were being produced and distributed, to work in conjunction with existing gas masks. Advances were also made in 
the preparation of cotton masks, with more detailed and effective processes being designed. Masks were to be soaked in $1 \mathrm{~kg}$ of sodium thiosulphate, $800 \mathrm{~g}$ of water, $150 \mathrm{~g}$ of glycerine, and 100 cubic centimetres of a mixture of soda bicarbonate (25\%) and water (75\%), although this was later changed to just soda bicarbonate. ${ }^{21}$ The solution was to be heated and the cotton submerged repeatedly until it retained a volume of liquid roughly twice its original weight. Oxygen canisters were also distributed to some frontline units as a means of combating asphyxiation in gas victims, when the protective measures had failed to prevent the gas from attacking a soldier's mucus membranes. ${ }^{22}$

While these were positive developments they were not without their problems. Although goggle production was picking up pace, it still could not meet demand and individual armies began to send representatives to Paris to purchase goggles for themselves. This often led to armies paying much higher prices than the war ministry could have negotiated and aroused the ire of GQG, which ordered that the practice be stopped. Likewise reports came back that the cotton the French were using was inadequate and often failed to absorb the amount of liquid required to make the mask effective. $^{23}$ On 24 May Joffre responded by asking the war ministry to provide only hydrophilic cotton, which would better absorb the necessary chemicals to protect the wearer against chlorine. This seemed to be an acceptable solution except that the hydrophilic cotton shrank when it was impregnated, thus reducing the coverage offered to the wearer. ${ }^{24}$ When GQG first learned about the unquestionable superiority of British gas masks the solution became obvious: abandon all previous efforts and switch over wholly to the British masks, which consisted of a very large pad of cotton which could be impregnated with sodium thiosulphate and later urinated on to increase its ability to absorb and neutralize chlorine gas (any moisture greatly increased the efficacy of early 
gas masks; the ammonia in urine further helped to neutralize chlorine which, along with its ubiquity, made it a good option). ${ }^{25}$

Franco-British liaison concerning gas during the weeks immediately following Second Ypres was actually quite good, despite the intense souring of their relationship as a result of that engagement. Both sides were very desirous of, if nothing else, getting whatever information they could out of their ally concerning anti-gas measures and both seemed fairly open in sharing their data. Unfortunately, their interaction does underline the utterly chaotic nature of the allied response to gas which had no real, clear direction and no over-arching institution capable of providing one. On 28 May a report was produced compiling the results of both French and British research. It confirmed that the Germans had used chlorine gas and that sodium thiosulphate was the best antidote: conclusions which were presented nearly a month after GQG had been aware of them, had informed all the French armies and had begun producing vast quantities of masks impregnated with sodium thiosulphate. ${ }^{26}$ It further confirmed the inefficacy of dry gas masks (a point which certain British officers had learned in action, much to their detriment), and went on to repeat the already-disproven claims that petard explosions might help to disperse gas clouds.

The panic and haste of the early days of gas research also led to the acceptance of some rather wild intelligence reports. In mid-May the British warned the French of their fears that the Germans were researching a method to shower advancing allied infantry with sulphuric acid. ${ }^{27}$ Whether the threat was real or not is unknown, but it forced GQG to devote resources to its study and develop some level of defence against it. Ultimately it was suggested that attacking infantry cover any exposed skin with petroleum jelly (of which the French army conveniently had 5 tonnes). ${ }^{28}$ Thus a fully supplied French 
infantryman on the attack would be expected to put on an anti-gas balaclava, goggles, and a cotton gas mask over the balaclava, and cover himself with petroleum jelly before going over the top. How a man was supposed to fight, much less lead, in this state is unclear.

$* \quad * \quad *$

By the end of May the French had also started to see returns in their development of methods for using poison gas themselves. Initially, it had been tough going. Before the war there had been only one factory in France producing chlorine (Motte-Breuil). Not only did it produce a very small amount of chlorine but, unsurprisingly, it was also funded by German capital; the French had no real chlorine production to call their own. ${ }^{29}$ French production of chlorine had been expanded by the war ministry's direction of powders and explosives as it was a key component in picric acid which itself was required for the manufacture of high explosives. The fact that chlorine was needed for high explosives made it excessively difficult to get in quantity at the height of the shell scandal in spring 1915. Nevertheless a small quantity was found for the gas programme and the French were able to begin testing.

The French first tested chlorine gas on 13 May 1915 at the military camp at Satory, where it was released on a 50-metre front. ${ }^{30}$ The tests were deemed successful and prompted further gas use and research. They also created a basis for the French to develop more concrete theories for the offensive uses of gas. It was understood that for a gas attack to be successful it was necessary that a sufficient density of gas be carried over to the enemy trenches. If this could be achieved with sufficient speed and surprise, the French would be rewarded with an utterly neutralized German front line in which, under 
the best of circumstances, the collapsed bodies of the gas victims would line the bottom of the trench thus keeping the gas from being absorbed into the soil; the gas would linger and pose a threat to any enemy reinforcements. ${ }^{31}$ Weiss, in the wake of this successful test, also pioneered the idea of using a smoke screen to disguise advancing infantry in conjunction with a gas attack to throw the enemy into confusion.

With the test at Satory acting as a green light for the expansion of the gas programme a more detailed doctrine for using gas in the field could be constructed. Engineers assigned to work with gas were organized into ' $\mathrm{Z}$ companies' to man 'system Z apparatuses': gas canisters. The canisters were familiar to most engineers as they did not differ from normal commercial tanks used to store compressed gas. ${ }^{32}$ Special care was to be taken in the construction of gas canister emplacements. As they needed to be in the front line to be effective, they were exposed not only to enemy shells but also to the eyes of the enemy, who would respond violently if he suspected a gas attack was being planned. ${ }^{33}$ As such, $\mathrm{Z}$ companies would need to balance the need to protect their gas canisters from enemy artillery, which posed by far the greatest risk to any gas operation, with the need to retain secrecy at all cost.

Indeed, one of the constant fears in any offensive gas operation was the possibility that the gas might be unleashed in friendly trenches. It was recommended that frontline trenches be held as thinly as possible in the build-up to a gas attack so as to minimize the damage that any accidental release would cause. ${ }^{34}$ Whenever possible gas emplacements were to be located in forward saps somewhat away from friendly infantry, and it was recommended that barriers be constructed behind gas emplacements to keep gas from pouring down French trenches. Extra space was to be dug behind any gas emplacement to ensure a continued ease of movement during the use and installation of gas canisters 
whose size and number would necessarily take up a considerable amount of space in the forward trenches. ${ }^{35}$ The work in setting up a series of gas positions would be done jointly by gas troops and local infantry; the engineers would take on a more supervisory role, with the majority of the heavy lifting being done by the infantry.

$\mathrm{Z}$ companies were made up of three sections, each holding a front of roughly one kilometre and consisting of 1 lieutenant, 1 adjutant (second lieutenant), 4 sergeants, 10 corporals, 100 men, 2 liaison agents, 6 kitchen staff, 1 medical orderly, 1 tailor or cobbler, 1 ordnance manager, and a reserve of 5 men for replacements as needed. ${ }^{36}$ Army meteorological sections were created and attached to each $\mathrm{Z}$ company. Their primary responsibility was to ascertain the feasibility of launching a gas attack on any particular day, as well as organizing the exact method of releasing gas so as to achieve the desired effect. A standard gas canister took six minutes to empty and each individual gas emplacement was to have five canisters. If the wind was fairly quick (10-16 kilometres per hour, for example), the gas would have to be unleashed as quickly as possible to ensure that an effective concentration of gas reached the enemy. ${ }^{37}$ Likewise in calm conditions the gas could be released more slowly and still achieve the desired effect. It would be up to the $\mathrm{Z}$ companies themselves to coordinate the timing of any gas attack as an uneven launch across a front of several kilometres might give the enemy sufficient warning to prepare for incoming gas, thus greatly reducing the efficacy of an attack.

While the French theory of gas warfare was reasonably advanced, it far outstripped French capabilities. So long as there was a shell shortage the French could not devote sufficient amounts of chlorine to develop large-scale gas attacks without adversely affecting the production of high explosives. Therefore, the allies would not 
launch any large second Ypres-style gas offensives until the British attack at Loos on 25 September 1915.

\section{Gas Shells}

Perhaps the most interesting project the French army undertook as it sought to broaden its use of chemical weapons was the development of poison gas shells. The first tests with fully functional gas shells occurred at Bourges in early May, with additional tests being run at Vincennes from 14 May $1915 .{ }^{38}$ Of the various shells tested the clear winner was a $75 \mathrm{~mm}$ shell, which fired a mixture of carbon bisulphide $\left(\mathrm{CS}_{2}\right)$ and phosphorus. This shell not only produced asphyxiating gas but was also incendiary and produced large quantities of smoke. ${ }^{39}$ The day after the initial tests at Vincennes Joffre expressed his keen interest in these shells and wrote to the war minister asking that shells be produced as quickly as possible so that they could be tested at the front. Joffre initially ordered 10,000 gas shells but not without taking into account the political implications. He expressed concern that any French use of gas, which might be considered to have surpassed the Germans' perceived barbarity in using poison gas first, would nullify the public-relations gold mine that the Germans had provided the allies during Second Ypres. ${ }^{40}$ He was especially concerned by the prospective development of cyanide and arsenic shells.

Nevertheless, within a fortnight of Joffre's order to begin producing gas shells for use at the front, a store of 4,000 shells and 2,000kg of phosphorus (each shell required 100g) had been built up at Vincennes. ${ }^{41}$ Despite Joffre's concerns, tests were already underway to assess the viability of hydrocyanic acid (cyanide, $\mathrm{HCN}$ ) shells, although the 
results were far from perfect. Hydrocyanic acid shells were loaded with two separate compartments; the outer contained $100 \mathrm{~g}$ of potassium cyanide $(\mathrm{KCN})$, while an inner chamber was filled with $125 \mathrm{cc}$ of hydrochloric acid (HCL). ${ }^{42}$ Upon detonation these two chemicals would mix and produce gaseous hydrocyanic acid. Unfortunately, tests found that the explosion of the shell happened so quickly that the chemical reaction to create hydrocyanic acid did not have sufficient time to finish and thus produced an inferior quantity of acid compared with normal laboratory procedures. ${ }^{43}$ Far more discouraging were the animal test results. In one test, a guinea pig was placed in a specially dug pit at Vincennes and exposed to the gas created from a single $75 \mathrm{~mm}$ shell explosion; the guinea-pig did not respond to the gas. The same guinea pig was then given a second blast and again failed to die. Undoubtedly frustrated, the experimenters got two fresh guinea pigs and exposed them to $2 \mathrm{~kg}$ of $\mathrm{KCN}$ and 2,700cc of $\mathrm{HCL}$ (representing the blast of 20 $75 \mathrm{~mm}$ shells) which were detonated so as to create hydrocyanic acid. The two guinea pigs, judiciously protected from the explosion, succumbed almost immediately to the resulting gas, thus proving that a fairly thick density would be needed if gas shells were to have any effect on the enemy. ${ }^{44}$

By the end of May tests had repeatedly shown the efficacy of gas shells and had won them the approval of the highest ranking French officers in GQG and the war ministry. On 31 May the order of gas shells was drastically increased from 10,000 to 50,000 and every effort was made to get gas shells into the field as soon as possible. ${ }^{45}$ By 9 June the original 10,000 were ready for deployment, with the first shipments headed for Tenth Army, by then having been engaged in active fighting north of Arras for a month. They were ready to be dispatched at 05.00 on the $10^{\text {th }}$, just in time for the $16-18$ June attack in Artois. The shells were shipped with their shell casings separate, as it was 
feared that completed shells were too volatile and might explode while in transit. Shells were to be shipped lying horizontally on single-bedded carts, and absolutely no smoking was allowed during the shells' transport owing to the highly flammable nature of carbon bisulphide. $^{46}$

Along with the shells went detailed instructions on their properties and use for the artillerymen to whom they would be supplied. The shells were described as highly flammable and as such were good against villages and other immobile, combustible defences. Their gas-producing qualities made them suited to attacking dugouts, wooded areas and cantonments, where the gas would not quickly dissipate. Above all else, the artillerymen were to ensure that a sufficient concentration of gas was deployed against a given target. ${ }^{47}$ This meant that they were best used in calm atmospheric conditions against carefully selected targets. The note initially stated that between 500 and 1,000 shells were needed to inundate sufficiently one hectare with poison gas, but this was crossed out by Joffre and replaced with simply $1,000 .{ }^{48}$ Since an enemy target had to be hit with a large volume of shells in as short a time as possible, it was strongly recommended that a large number of batteries be used so as to keep guns from overheating. Achieving such a concentration of gas was made slightly easier by all gas shells having 'instant' as opposed to timed fuses, to ensure that they did not prematurely explode above the German trenches, thus making an effective use of gas all but impossible. ${ }^{49}$ As the French did not have a sufficient supply of gas masks the infantry could not advance into a gassed area, and so gas shells would be best targeted against areas in the enemy rear. Gas shells could not be used in conjunction with explosive shells as their explosion might disperse the accumulated gas. It was proposed however that, if gas shells were used against more forward positions, high explosive shells might be used 
to disperse the gas, thus allowing the French infantry to advance. At the end of the typewritten document Joffre signed his name and in blue ink expressed his keen desire to receive information on the results of the first gas shell attack as soon as possible.

The first launch of gas shells took place seven days later, on 16 June. At 21.05 on 17 June Joffre sent a telegram to Ferdinand Foch, then commanding the Groupe Provisoire du Nord (Provisional Northern [Army] Group, or GPN), under whose direction the second battle of Artois was being fought, urgently demanding information on the use of gas shells in order to decide whether or not the additional shells being produced (a second 10,000 were ready) should be sent out to Tenth Army. ${ }^{50}$ Foch responded two hours later, saying that he did not have enough information to provide a full report but that he would give Joffre his initial impressions. Thus far, only $10 \%$ of shells fired were seen to produce a fireball, which meant that they were not producing the incendiary effect that had been desired. Fortunately, however, the shells produced prodigious amounts of smoke and were responsible for completely silencing the enemy batteries against which they had been launched, and as such they should be judged a huge success; Foch urged Joffre to send him the next delivery of 10,000 gas shells. ${ }^{51}$

A few weeks later a full report was compiled on the use of gas shells from 16 to 18 June 1915. The precautions in transport had proven effective and there had been not a single incident of shells going off accidentally. Gas shells had been fired at a rate of one round per gun per minute with five guns assigned to each hectare of enemy terrain. ${ }^{52}$ Observation was made easy by the large plumes of smoke the shells emitted. The main targets were Souchez, Angres, the Château Carleul, and various enemy battery emplacements (mostly in wooded areas), including La Folie, a farm near Vimy ridge. ${ }^{53}$ According to the report the already dilapidated state of Souchez, which had been the 
subject of intense French fire since 9 May, prohibited any incendiary effect the shells might have had. The shells did seem to have better luck in Angres, however, as multiple fires were seen raging through the village within hours of the gas shell attack. The asphyxiating nature of the shells fired on Souchez and Angres could not be easily verified, with the note snidely asserting that only the gas victims were in a position to confirm their efficacy. Where the attack really shone was in silencing enemy batteries, a fact which the report highlights. On 17 June a bombardment of gas shells fired into La Folie, the location of large numbers of German batteries, managed to silence the German artillery in front of the French XX CA for an hour and half, thus greatly facilitating a simultaneous infantry attack. Based on this, the report very warmly suggested the mass expansion of the army's gas shell use. On 27 June, four days after the report was issued, this proposal was reinforced by the war ministry which expressed its full support for the increased use and production of gas shells and gas bombs, which were to be dropped from aeroplanes.

Chemical warfare had been warmly embraced by the French, who pioneered the use of chemical weapons for the neutralization of enemy batteries as opposed to using gas clouds to subdue enemy infantry. This would go on to be an important tactical development as the armies on the western front eventually moved from destruction towards neutralization as a guiding principle in preparing trench offensives. It is important to note that this advance was not the result of any particular genius on the part of the French. Instead, it was an adaptation to the material constraints of a nation which had lost key swathes of its industrial heartland in the opening months of the war, and never boasted a significant chemicals industry. The development of effective gas shells clearly shows that the French did add certain refinements to chemical warfare during the 
Great War. The acknowledgement of this fact, in conjunction with very recent

historiography on the evolution of French tactics and operational thought during the war, facilitates a further reappraisal of the French efforts in 1914-1918.

\footnotetext{
${ }^{1}$ Haber, The Poisonous Cloud, p. 23 \& Moore, Gas Attack!, p. 7

${ }^{2}$ Cook, No Place to Run, pp. 65-67

3 Trumpener, 'The Road to Ypres', p. 462

${ }^{4}$ Haber, The Poisonous Cloud, p. 53

${ }^{5}$ Haber, The Poisonous Cloud, p. 53

${ }^{6}$ Haber, The Poisonous Cloud, pp.16-17

${ }^{7}$ Moore, Gas Attack!, p. 2

${ }^{8}$ Olivier Lepick, La Grande Guerre Chimique, 1914-1918 (Paris: Presses Universitaires de France, 1998);

«En l'espace de quelques mois, l'arme chimique allait passer du rang de curiosité technique à celui de vecteur indispensable de la guerre moderne. "

${ }^{9}$ Service Historique de la Défense (SHD), 16N826; "Rapport sur l'organisation du Service du Matériel Chimique de Guerre, présenté par M. D’Aubigny, Depute » 25 Août 1915

${ }^{10}$ SHD, 16N832; "Le Ministre de la Guerre à M. le Général Commandant en Chef »17 Avril 1915

${ }^{11}$ SHD, 16N832; "Le Général Commandant en Chef à M. le Général Commandant l'Armée (Toutes Armées - D.A.. - D.A.L. » 20 Avril 1915

${ }^{12}$ SHD, 16N826; "Rapport sur l'organisation du Service du Matériel Chimique de Guerre, présenté par M. D’Aubigny, Depute » 25 Août 1915

${ }^{13}$ SHD, 16N832; "Ministre Guerre - 4 Direction - $2^{e}$ Bureau à Général commandant en chef » 24 Avril 1915 , reçu 15.10

${ }^{14}$ Unfortunately, the full names of two of the three principal civilians involved in the early French gas programme have not survived. They are here listed simply as 'monsieur', as they are in the original documentation.

${ }^{15}$ SHD, 16N826; "Rapport sur l'organisation du Service du Matériel Chimique de Guerre, présenté par M. D'Aubigny, Depute » 25 Août 1915

${ }^{16}$ SHD, 16N832; "Le Général en chef à M. le Ministre de le Guerre » 25 Avril 1915

${ }^{17}$ SHD, 16N832; "Général Foch à Etat Major Chantilly » 27 Avril 1915

${ }^{18}$ SHD, 16N826; "Rapport sur l'organisation du Service du Matériel Chimique de Guerre, présenté par M. D’Aubigny, Depute » 25 Août 1915

${ }^{19}$ SHD, 16N832; "Note pour les Armées » 30 Avril 1915

${ }^{20}$ SHD, 16N832; "Le Ministre de la Guerre à M. le Général Commandant en Chef » 9 Mai 1915

${ }^{21}$ SHD, 16N832; "Le Ministre de la Guerre à M. le Général Commandant en Chef » 8 Mai 1915

${ }^{22}$ SHD, 16N832; "Le Général Commandant en chef à M. le Commandant de l'Armée » 11 Mai 1915

${ }^{23}$ SHD, 16N832; "Le Général Commandant en Chef à M. le Général D.E.S. à Hesbin » 24 Mai 1915

${ }^{24}$ SHD, 16N832; "Le Général Commandant en Chef à M. le Général D.E.S. à Hesbin » 24 Mai 1915

${ }^{25}$ SHD, 16N832; "Le Général Commandant en Chef à Monsieur le Ministre de la Guerre » 27 Mai 1915

${ }^{26}$ SHD, 16N832; "Instruction au sujet de la lutte contre le gaz » 28 Mai 1915

${ }^{27}$ SHD, 16N832; "Le Ministre de la Guerre à M. le Général Commandant en Chef »14 Mai 1915

${ }^{28}$ SHD, 16N832; "Le Ministre de la Guerre à M. le Général Commandant en Chef »14 Mai 1915

${ }^{29}$ SHD, 16N826; "Rapport sur l'organisation du Service du Matériel Chimique de Guerre, présenté par M. D’Aubigny, Depute » 25 Août 1915

${ }^{30}$ SHD, 16N826; « Gaz Asphyxiant, Compte-rendu des essais du 13 Mai » 14 Mai 1915

${ }^{31}$ SHD, 16N826; «Gaz Asphyxiant, Compte-rendu des essais du 13 Mai » 14 Mai 1915

${ }^{32}$ SHD, 16N826; "Gaz Asphyxiant, Compte-rendu des essais du 13 Mai » 14 Mai 1915

${ }^{33}$ SHD, 16N826; "Gaz Asphyxiant, Compte-rendu des essais du 13 Mai » 14 Mai 1915

${ }^{34}$ SHD, 16N826; "Gaz Asphyxiant, Compte-rendu des essais du 13 Mai » 14 Mai 1915

${ }^{35}$ SHD, 16N826; "NOTICE sue la procède d'émission de gaz asphyxiant au moyen des appareils système $Z 2$ et sur l'organisation es compagnies des sapeurs chargés de la mise en ceuvre de ces appareils » Ministère de la Guerre
} 
${ }^{36}$ SHD, 16N826; "NOTICE sue la procède d'émission de gaz asphyxiant au moyen des appareils système $Z 2$ et sur l'organisation es compagnies des sapeurs chargés de la mise en ouvre de ces appareils »

Ministère de la Guerre

${ }^{37}$ SHD, 16N826; "NOTICE sue la procède d'émission de gaz asphyxiant au moyen des appareils système $Z 2$ et sur l'organisation es compagnies des sapeurs chargés de la mise en ouvre de ces appareils »

Ministère de la Guerre

${ }^{38}$ SHD, 16N707; "Compte-rendu du 14 Mai $1915 »$ G.Q.G.

${ }^{39}$ SHD, 16N707; «Compte-rendu du 14 Mai $1915 »$ G.Q.G.

${ }^{40}$ SHD, 16N707; «Le Général Commandant en Chef à M. le Ministre de la Guerre ( $3^{\text {ème }}$ Direction) » 28 Mai 1915

${ }^{41}$ SHD, 16N707; «Compte-rendu du 28 Mai » G.Q.G.

${ }^{42}$ SHD, 16N707; "Compte-rendu du 28 Mai » G.Q.G.

${ }^{43}$ SHD, 16N707; «Compte-rendu du 28 Mai » G.Q.G.

${ }^{44}$ SHD, 16N707; «Compte-rendu du 28 Mai » G.Q.G.

${ }^{45}$ SHD, 16N707; «Le Ministre de la Guerre à M. le Général Commandant en Chef » 31 Mai 1915

${ }^{46}$ SHD, 16N707; «Note pour la D.A. »9 Juin 1915

${ }^{47}$ SHD, 16N707; «Note pour la D.A. »9 Juin 1915

${ }^{48}$ SHD, 16N707; « Note pour la D.A. »9 Juin 1915

${ }^{49}$ SHD, 16N707; «Note pour la D.A. »9 Juin 1915

${ }^{50}$ SHD, 16N707; «Télégramme chiffre ; Général Commandant en Chef à Général Foch Cassel » 17 Juin $1915 ; 21.05$

${ }^{51}$ SHD, 16N707; «Traduction d'un télégramme chiffre ; Général Foch à EM G.Q.G. »17 Juin 1915 ;

23.10

${ }^{52}$ SHD, 16N707; «Compte-rendu au sujet des obus spéciaux de 75 » 23 Juin 1915

${ }^{53}$ SHD, 16N707; «Compte-rendu au sujet des obus spéciaux de 75 » 23 Juin 1915 